\title{
PERCEPTION OF ACCOUNTANT PROFESSION IN THE CZECH REPUBLIC
}

\author{
[Vnímání účetní profese v České republice] \\ Beáta Blechová ${ }^{1}$, Ivana Koštuříková ${ }^{2}$, Markéta Šeligová ${ }^{3}$ \\ ${ }^{1}$ Slezská univerzita, Obchodně podnikatelská fakulta, Univerzitní nám. 1934/3,733 40 Karviná \\ Email:blechova@opf.slu.cz. \\ ${ }^{2}$ Slezská univerzita, Obchodně podnikatelská fakulta, Univerzitní nám. 1934/3,733 40 Karviná \\ Email:kosturikova@opf.slu.cz \\ ${ }^{3}$ Slezská univerzita, Obchodně podnikatelská fakulta, Univerzitní nám. 1934/3,733 40 Karviná \\ Email:seligova@opf.slu.cz
}

\begin{abstract}
The aim of the article is to evaluate the perception of the accountant profession in the Czech Republic by students of full-time and combined study at the School of Business Administration in Karviná. In order to achieve the objective of the article, a questionnaire survey was used. On the basis of the acquired nominal data, the perceptions of the accountant profession were examined using Pearson's chi-quadrate test and the Pearson's coefficient of contingency. It can be concluded from the results that the perception of entrepreneurial risk associated with choosing a professional accountant does not depend on the form and field of university studies. On the other hand, the form of university studies influences the perception of whether the level of qualifications of professional accountants is reflected in their salary assessment and whether, due to the economic decline of previous years, the importance of professional accountants for entrepreneurs has increased. It was also found that the perceptions of the accountant profession in the Czech Republic are not dependent on the level of university studies. The results also show that the perception of the impact of the economic downturn over the past years on increasing the importance of professional accountants for entrepreneurs is not dependent on the field of study. The results also showed that the perceptions of accountants in the Czech Republic depend on employment.
\end{abstract}

Keywords: accountatn profession, enterpreneurial risk, Pearson coefficient, Pearson's chi-quadrate test, qualifications of professional accountants, questionnaire survey, university studies.

JEL classification: M4, M40, M41

Received: 12.11.2018; Reviewed: 16.11.2018; 20.11.2018; 21.11.2018; Accepted: 30.10.2019

\section{Úvod}

Prostředí, ve kterém účetní jednotky realizují svou podnikatelskou činnost, se neustále vyvíjí a mění. Hnací silou těchto změn je mezi jinými postupná globalizace, technický pokrok, inovace, ale i měnící se sociální hodnoty, diverzifikace lidských zdrojů nebo využívání přírodního prostředí. Tyto změny se promítají do účetnictví, a tím následně ovlivňují účetní výkaznictví. V dnešní době je stále více kladen důraz na zvýšení transparentnosti finančního výkaznictví a současně roste zájem o nefinanční informace. To je důvodem postupné evaluace profese účetních, jejíž náplní není jen vedení účetnictví, ale poskytování komplexních informací včetně daňových nebo finančních. $Z$ tohoto pohledu je účetnictví široká oblast, do které se prolíná téměř vše, co souvisí s vedením a řízením firmy.

Z tohoto důvodu je cílem článku zhodnotit vnímání účetní profese v České republice studenty prezenční a kombinované formy studia na Obchodně podnikatelské fakultě v Karviné. Pro určení závislosti vnímání účetní profese na formě vysokoškolského studia, stupni vysokoškolského studia a oboru vysokoškolského studia a zaměstnání byly stanoveny 
následující hypotézy, jež byly rozděleny do 4 skupin (dle formy vysokoškolského studia, stupně vysokoškolského studia, oboru vysokoškolského studia a zaměstnání).

Pro prověření závislosti vnímání účetní profese na formě vysokoškolského studia byly stanoveny následující hypotézy:

- vnímání podnikatelského rizika spojeného s výběrem profesního účetního nezávisí na formě vysokoškolského studia,

- vnímání, zda se úroveň kvalifikace profesních účetních projevuje na jejich platovém ohodnocení, nezávisí na formě vysokoškolského studia,

- vnímání, zda vlivem ekonomického poklesu uplynulých let došlo ke zvýšení důležitosti profesních účetních pro podnikatele, nezávisí na formě vysokoškolského studia.

Pro analýzu závislosti vnímání účetní profese na stupni vysokoškolského studia byly stanoveny další tři hypotézy:

- vnímání podnikatelského rizika spojeného s výběrem profesního účetního nezávisí na stupni vysokoškolského studia,

- vnímání, zda se úroveň kvalifikace profesních účetních projevuje na jejich platovém ohodnocení, nezávisí na stupni vysokoškolského studia,

- vnímání, zda vlivem ekonomického poklesu uplynulých let došlo ke zvýšení důležitosti profesních účetních pro podnikatele, nezávisí na stupni vysokoškolského studia.

V neposlední řadě byla také zkoumána závislost vnímání účetní profese na oboru vysokoškolského studia. Pro testování byly stanoveny tyto hypotézy:

- vnímání podnikatelského rizika spojeného s výběrem profesního účetního nezávisí na oboru studia,

- vnímání, zda se úroveň kvalifikace profesních účetních projevuje na jejich platovém ohodnocení, nezávisí na oboru studia,

- vnímání, zda vlivem ekonomického poklesu uplynulých let došlo ke zvýšení důležitosti profesních účetních pro podnikatele, nezávisí na oboru studia.

Prověření závislosti vnímání účetní profese na zaměstnání bylo uskutečněno pomocí testování následujících hypotéz:

- vnímání podnikatelského rizika spojeného s výběrem profesního účetního nezávisí na zaměstnání,

- vnímání, zda se úroveň kvalifikace profesních účetních projevuje na jejich platovém ohodnocení, nezávisí na zaměstnání,

- vnímání, zda vlivem ekonomického poklesu uplynulých let došlo ke zvýšení důležitosti profesních účetních pro podnikatele, nezávisí na zaměstnání.

V rámci výzkumu bylo osloveno 1035 studentů, přičemž dotazník vyplnilo 709 osob. Šetření se zúčastnilo 252 studentů prezenční formy a 457 studentů kombinované formy studia. Většina studentů (521) byla z bakalářského stupně studia, v rámci kterého absolvovali předměty jako například Finanční účetnictví, Nákladové účetnictví a Účetní a daňové praktikum. Navazující magisterský stupeň navštěvovalo 188 studentů, kteří absolvovali předměty jako Účetnictví obchodních společností a Mezinárodní účetnictví a účetní standardy. Obor Účetnictví a daně studovalo 178 respondentů, dalších 531 dotázaných absolvovalo jiné ekonomické obory.

První část článku bude zaměřena na přehled literatury, ve které budou zmíněny studie zabývající se obdobným tématem. Další část je věnována charakteristice dat a metodologie. 
Třetí část článku bude obsahovat výsledky výzkumu a následnou diskusi nad zjištěnými výsledky.

\section{Přehled literatury}

Jak již bylo zmíněno výše, prostředí, ve kterém realizují svou činnost účetní jednotky, se neustále vyvíjí a mění. Hnací silou těchto změn je mezi jinými postupná globalizace, technický pokrok, inovace, ale i měnící se sociální hodnoty, diverzifikace lidských zdrojů nebo využívání přírodního prostředí. Tyto změny se promítají do účetnictví a tím následně ovlivňují účetní výkaznictví. V dnešní době je stále více kladen důraz na zvýšení transparentnosti finančního výkaznictví a současně roste zájem o nefinanční informace.

To je důvodem postupné evaluace profese účetních, jejíž náplní není jen vedení účetnictví, ale poskytování komplexních informací včetně daňových nebo finančních. Z tohoto pohledu je účetnictví široká oblast, do které se prolíná téměř vše, co souvisí s vedením a řízením firmy. $\mathrm{S}$ rostoucím významem účetních informací pro management účetní jednotky v souvislosti s jejím finančním rozhodováním roste role kvalitního profesního účetního. Paseková et al. (2018) se domnívají, že účtování by nemělo být používáno pouze jako zdroj informací, který nám umožňuje vypočítat výši daňové povinnosti a sestavit požadované výkazy. Účtování spolu $\mathrm{s}$ dalšími nástroji finančního řízení by mělo být zdrojem úplných údajů jak pro interní, tak pro externí uživatele. Účtování zajišt'uje určité typy kvantitativních informací pro rozhodování a řízení společnosti. Účetní informace se pro většinu zájmových skupin staly základním zdrojem informací o společnosti (Otrusinová a Šteker 2013).

Účetní profesi lze jen stěží definovat. Dle členky Komory certifikovaných účetních Pšeničkové mohou malé účetní jednotky vnímat své účetní jako rovnocenné partnery, kdežto velké firmy vnímají účetní jako nepostradatelnou profesi, která však podniku negeneruje žádný zisk. Přitom kvalifikovaný a schopný účetní dokáže podniku ušetřit nemalé finance.

Dle Šípkové (2013) účetní profese může ve stabilizaci podnikatelského prostředí sehrát zcela zásadní roli. Důvěryhodnost účetní profese záleží na tom, jak veřejnost vnímá hodnotu, kterou finanční profesionálové přinesou. Informace z účetnictví jsou důležité pro manažerské rozhodování. Čím vyšší je podíl účetní profese na rozhodování o strategii, hledání obchodních př́iležitostí nebo řízení rizik účetní jednotky, tím větší je její význam (Jaworska 2016).

Dle IFAC (2009) patří mezi hlavní úkoly profesních účetních například vedení účetnictví v souladu s legislativou, analýza a interpretace účetních informací pro podnikovou strategii a ekonomické rozhodování, zajištění vnitřní kontroly, řízení rizik, evidování obchodních operací. Úlohou účetních specialistů je dle Gibassiera (2015) mezi jinými zpracování klíčových ukazatelů úspěšnosti účetní jednotky a jejich monitorování. Za účelem poskytnutí relevantních informací by účetní měl dodržovat pravidla a zásady, na nichž je založeno zpracování účetních údajů (Puican et al. 2011).

Dle Suddabye, Gendrona a Lama (2009) jsou profesní účetní definování jako strážci veřejného zájmu. Jejich vlastnostmi by měla být profesní odbornost, zkušenost, nezávislost, čestnost a objektivita. Význam profesních účetních je předmětem výzkumu a odborných studií mezinárodních organizací jako je např́klad IFAC (2011) nebo ACCA (2012). Problematika významu profesních účetních a rostoucích požadavků na jejich odbornost začala být v ČR více diskutována od roku 2014, kdy byl posílen institut odpovědnosti členů statutárních orgánů. Podle Zákona o obchodních korporacích je statutární orgán zodpovědný za zajištění správného vedení účetnictví v souladu s konceptem péče řádného hospodáře. 
V České republice se problematikou profesních účetních zabývá například Komora certifikovaných účetních, která se v rámci mezinárodního projektu , Rozvoj lidských zdrojů v oblasti certifikovaných účetních" zaměřila na problematiku zlepšení postavení certifikovaných účetních na trhu práce, zvýšení jejich prestiže a dalšího vzdělání.

Podle průzkumu Komory certifikovaných účetních více než 69 \% odborně kvalifikovaných finančních účetních v Česku se domnívá, že úroveň jejich kvalifikace by měl určovat samotný trh, $71 \%$ dotázaných je přesvědčeno, že podnikatelé rizika spojená s nesprávnou volbou účetního v současnosti plně nedoceňují. Zaměstnavatelé často mylně vnímají účetní pouze jako nákladovou položku nepřinášející zisk, přitom kvalifikovaný, erudovaný a zkušený účetní může managementu poskytnout nejen účetní, ale i daňové a právní informace, které jsou významné pro jeho ekonomické rozhodování.

\section{Data a metodologie}

V rámci interního projektu „Nové trendy a specifika účetnictví v kontextu legislativních změn v ČR“ byl mimo jiné zkoumán pohled studentů ekonomické vysoké školy na účetní profesi v České republice. Formou dotazníkového šetření bylo zjišt'ováno, jak studenti prezenční i kombinované formy studia na Obchodně podnikatelské fakultě vnímají účetní profesi v České republice. V rámci výzkumu bylo osloveno 1035 studentů, přičemž dotazník vyplnilo 709 osob. $\mathrm{Na}$ základě získaných nominálních dat bylo vnímání účetní profese zkoumáno pomocí Pearsonova chí-kvadrát testu jejich nezávislost $\mathrm{v}$ kontingenční tabulce. Byly stanoveny hypotézy $\mathrm{H}_{0}$, že sledované znaky jsou nezávislé. Byly porovnávány empiricky zjištěné četnosti $\left(\mathrm{n}_{\mathrm{ij}}\right) \mathrm{s}$ četnostmi teoretickými, neboli očekávanými $\left(\mathrm{e}_{\mathrm{ij}}\right)$, které představují sdružené četnosti očekávané za předpokladu nezávislosti proměnných. Velikost rozdílů mezi pozorovanými a očekávanými četnostmi posuzujeme pomocí testové statistiky (1).

$$
\chi^{2}=\sum_{i=1}^{r} \sum_{j=1}^{c} \frac{\left(n_{i j}-e_{i j}\right)^{2}}{e_{i j}}
$$

Testové kritérium $\chi^{2}$ má při platnosti hypotézy $\mathrm{H}_{0}$ a za předpokladu, že všechny teoretické četnosti $\mathrm{e}_{\mathrm{ij}}$ jsou větší než $1 \mathrm{a}$ alespoň $80 \% \mathrm{z}$ nich je větší než 5 , přibližně Pearsonovo $\chi^{2}(v)$ rozdělení se stupni volnosti (2).

$$
v=(r-1)(c-1)
$$

Hypotéza $\mathrm{H}_{0}$ o nezávislosti se pak zamítá na hladině významnosti $\alpha$, když hodnota testové statistiky $\chi^{2}$ přesáhne př́slušný $100(1-\alpha) \%$ kvantil rozdělení $\chi^{2}(3)$.

$$
\chi^{2} \geq \chi_{1-\alpha}^{2}(v)
$$

Pro testování hypotéz s použitím Pearsonova chí-kvadrát testu byl využit statistický program SPSS, s jehož pomocí byla vypočítána hladina statistické významnosti, neboli signifikance (tzv. p-hodnota). Dosažená hladina statistické významnosti byla zkoumána na hladině významnosti $\alpha=0,05$. Je-li p-hodnota větší než 0,05 , nulovou hypotézu nelze zamítnou.

V prrípadě zamítnutí nulové hypotézy pak byla dále zkoumána intenzita (těsnost) závislosti pomocí Pearsonova koeficientu kontingence (4). 


$$
C=\sqrt{\frac{\chi^{2}}{n+\chi^{2}}}
$$

Čím je koeficient blíže 1, tím je závislost mezi znaky těsnější, čím je blíže $\mathrm{k} 0$, tím je závislost slabší.

\section{Výsledky a diskuse}

Jak již bylo zmíněno, $v$ rámci interního projektu „Nové trendy a specifika účetnictví v kontextu legislativních změn v ČR" bylo zkoumáno vnímání účetní profese v České republice studenty prezenční a kombinované formy studia na Obchodně podnikatelské fakultě v Karviné. Šetření se zúčastnilo 252 studentů prezenční formy a 457 studentů kombinované formy studia. Většina studentů (521) byla $\mathrm{z}$ bakalářského stupně studia, 188 studentů navštěvovalo navazující magisterský stupeň. Obor Účetnictví a daně studovalo 178 respondentů, dalších 531 dotázaných absolvovalo jiné ekonomické obory.

\subsection{Vnímání účetní profese dle formy, stupně a oboru studia}

Studenti prezenční i kombinované formy studia vnímají riziko podnikatelů spojené s výběrem profesního účetního velmi podobně. Nepatrné rozdíly ve vnímání rizika jsou pak mezi studenty bakalářského a navazujícího magisterského stupně. Rozdíl je patrný rovněž u studentů oboru Účetnictví a daně a jiných oborů.

Obrázek 1: Vnímání podnikatelského rizika spojeného s výběrem profesního účetního podle formy, stupně a oboru studia

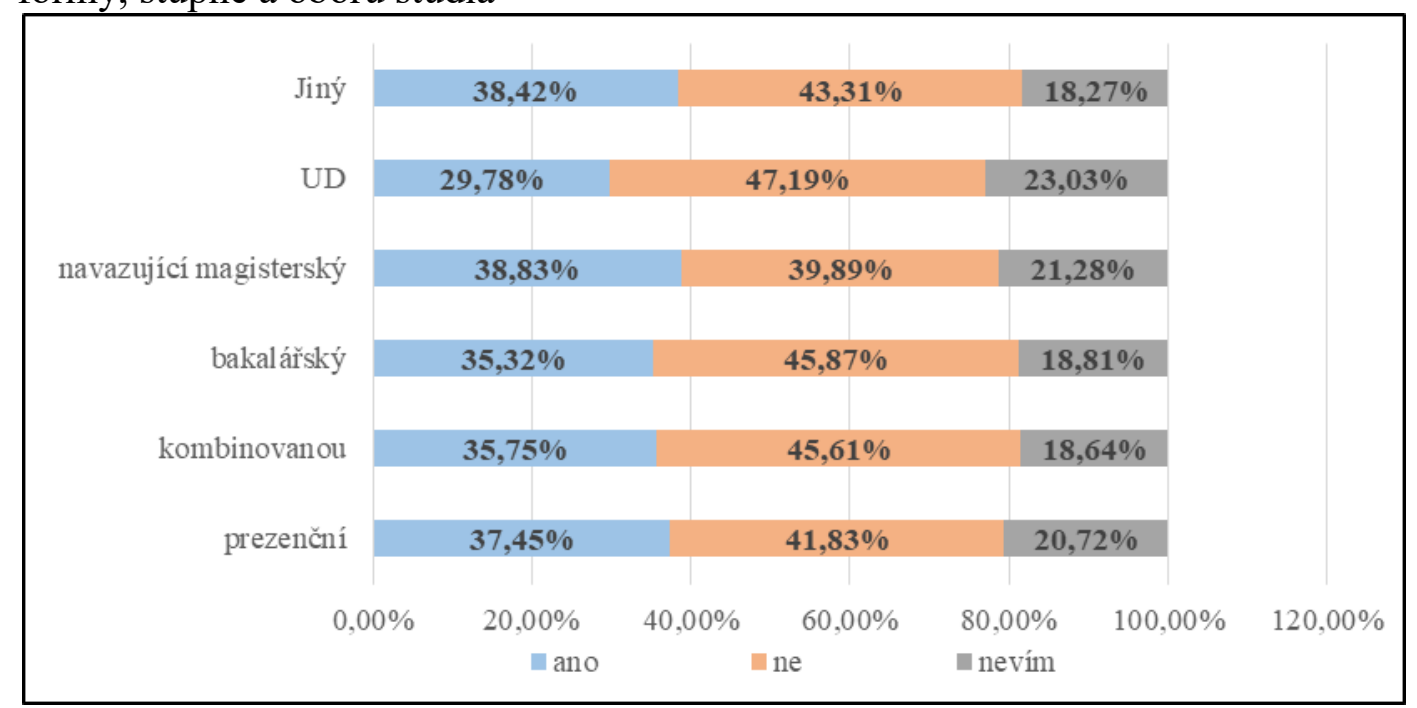

Zdroj: vlastní zpracování

Rovněž u vnímání vlivu úrovně kvalifikace profesních účetních na platovém ohodnocení je patrný rozdíl mezi studenty prezenční a kombinované formy studia, kdy $41 \%$ studentů prezenční formy studia nemá povědomí o tomto vlivu, kdežto stejné procento studentů kombinované formy studia se domnívá, že na současném trhu práce se úroveň kvalifikace účetní profese neprojevuje na jejich platovém ohodnocení. 
Obrázek 2: Vnímání vlivu úrovně kvalifikace profesních účetních na platovém ohodnocení podle formy, stupně a oboru studia

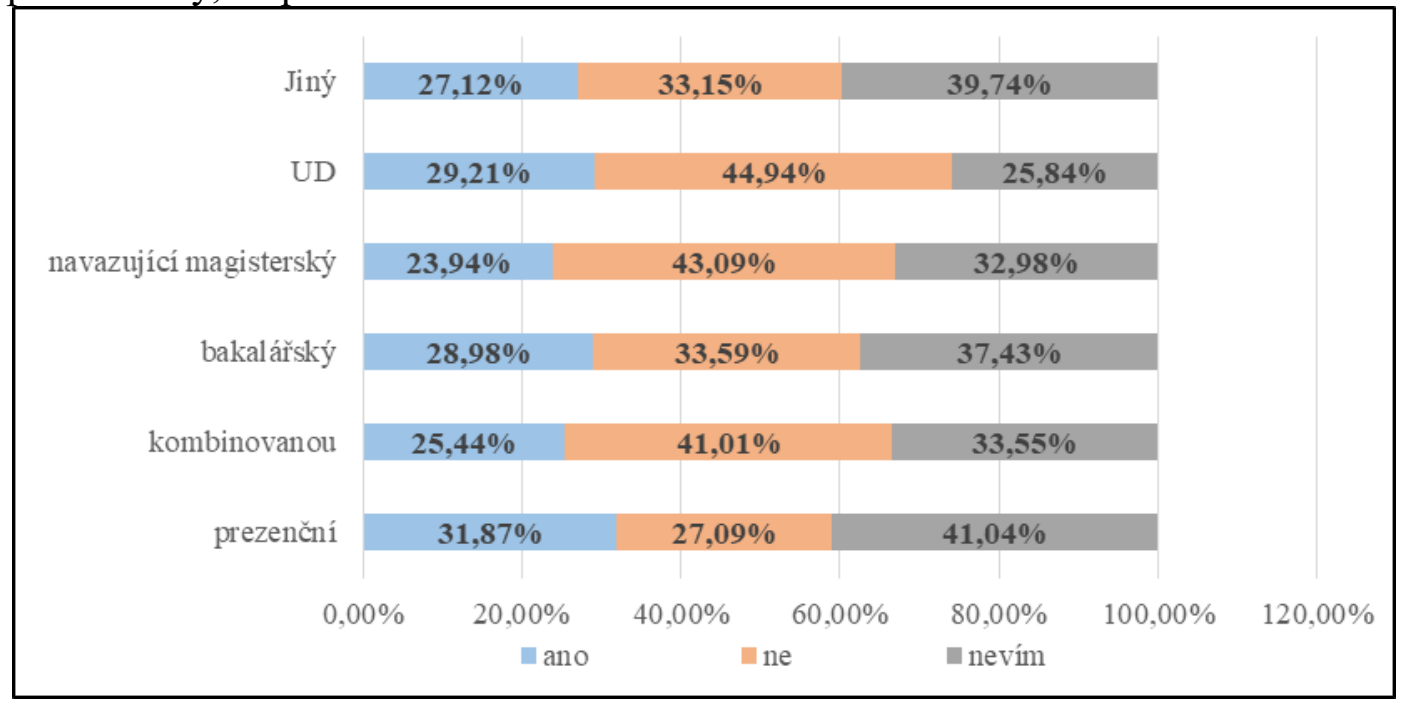

Zdroj: vlastní zpracování

$\mathrm{Na}$ předchozím obrázku 2 lze opět spatřit rozdílné vnímání u studentů bakalářského a navazujícího stupně studia, menší rozdílnost ve vnímání dané skutečnosti lze pak vidět u studentů jiných oborů a oboru Účetnictví a daně.

Obrázek 3: Vnímání vlivu ekonomického poklesu uplynulých let na důležitost účetní profese pro podnikatele podle formy, stupně a oboru studia

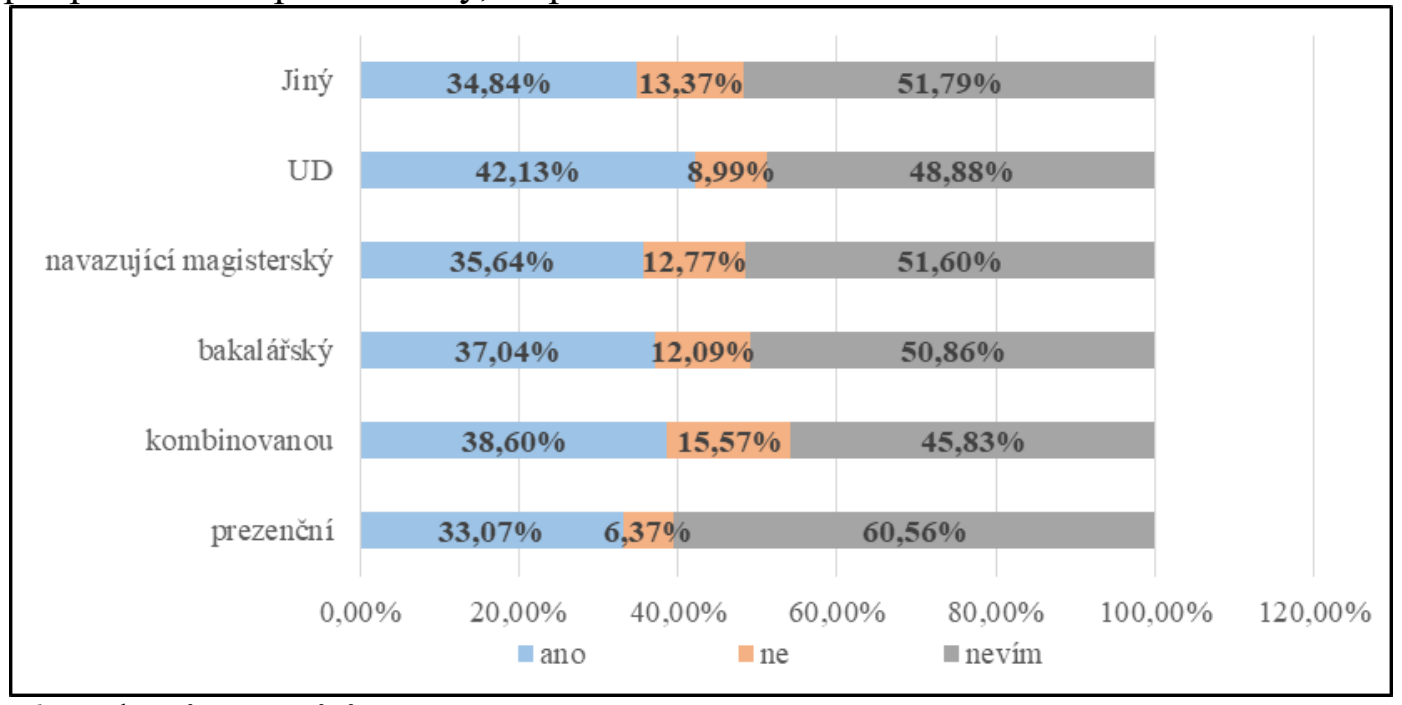

Zdroj: vlastní zpracování

Z obrázku 3 je patrné, že co se týče vnímání vlivu ekonomického poklesu uplynulých let na důležitost účetní profese pro podnikatele, je opět patrný rozdíl u studentů prezenční a kombinované formy studia. Z pohledu stupně studia vnímají tuto skutečnost bakaláři i navazující magistři velmi podobně. Studenti oboru Účetnictví a daně vyjádřili v tomto ohledu kladný postoj ve větší míře než studenti ostatních oborů. 


\subsection{Vnímání účetní profese dle zaměstnání}

Nemalé množství studentů bez ohledu na formu studia bylo nebo stále je v pracovněprávním vztahu. V ekonomickém oboru pracovalo 264 respondentů, 292 dotázaných vykonávalo neekonomickou profesi a 153 studentů nebylo v žádném pracovním poměru. Bylo zkoumáno, jakým způsobem ovlivňuje tato skutečnost vnímání účetní profese v České republice. Podobným způsobem vnímají podnikatelské riziko spojené s výběrem profesních účetních nepracující studenti a studenti, kteří jsou zaměstnáni v neekonomickém oboru (obr. 4).

Obrázek 4: Vnímání podnikatelského rizika spojeného s výběrem profesního účetního podle zaměstnání

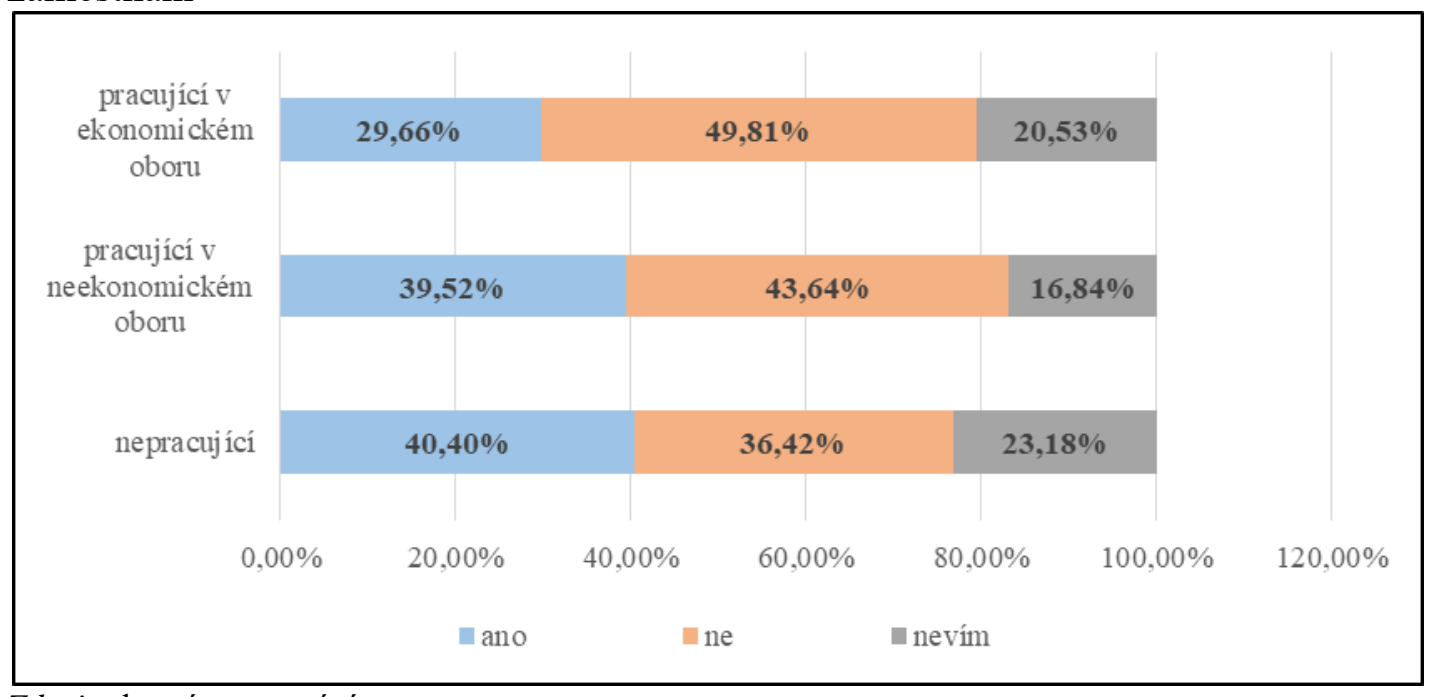

Zdroj: vlastní zpracování

Z následujícího obrázku 5 je patrné, že podobně vnímají nepracující a pracující v neekonomickém oboru vliv úrovně kvalifikace profesních účetních na jejich platové ohodnocení.

Obrázek 5: Vnímání vlivu úrovně kvalifikace profesních účetních na platovém ohodnocení podle zaměstnání

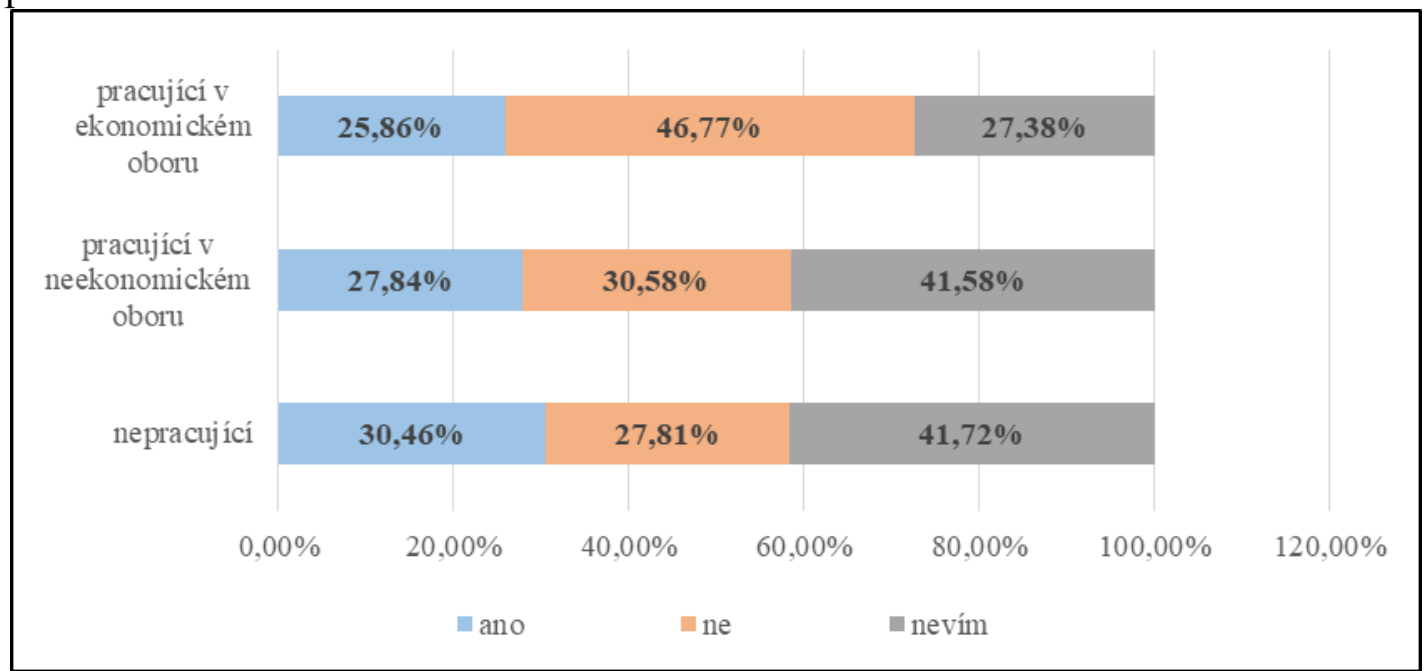

Zdroj: vlastní zpracování

Téměř $59 \%$ nepracujících a téměř $53 \%$ pracujících v neekonomickém oboru není schopno posoudit vliv ekonomického poklesu uplynulých let na zvýšení důležitosti profesních účetních 
pro podnikatele. U pracujících v ekonomickém oboru je to ,jen“ něco málo přes $44 \%$, když $39 \%$ z nich si tento vliv uvědomuje (obr. 6).

Obrázek 6: Vnímání vlivu ekonomického poklesu uplynulých let na důležitost účetní profese pro podnikatele podle zaměstnání

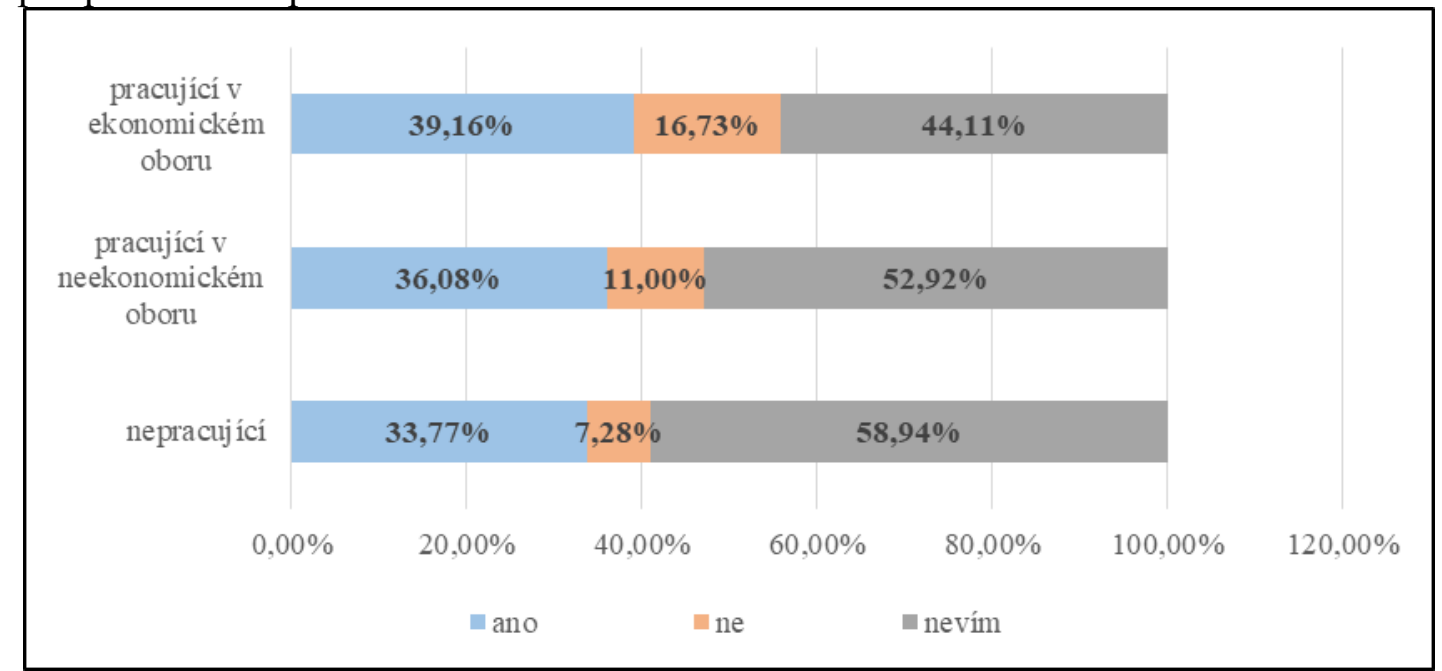

Zdroj: vlastní zpracování

\subsection{Závislost vnímání účetní profese na formě, stupni a oboru studia}

Pro prověření závislosti vnímání účetní profese na formě studia byly stanoveny následující hypotézy:

- vnímání podnikatelského rizika spojeného s výběrem profesního účetního nezávisí na formě vysokoškolského studia,

- vnímání, zda se úroveň kvalifikace profesních účetních projevuje na jejich platovém ohodnocení, nezávisí na formě vysokoškolského studia,

- vnímání, zda vlivem ekonomického poklesu uplynulých let došlo ke zvýšení důležitosti profesních účetních pro podnikatele, nezávisí na formě vysokoškolského studia.

Tabulka 1: Vnímání účetní profese podle formy vysokoškolského studia

\begin{tabular}{|l|c|c|c|c|}
\hline \multicolumn{2}{|c|}{ Chi-Square Tests } & Value & df & Asymp. Sig. \\
\hline $\begin{array}{l}\text { Podnikatelské riziko a výběr } \\
\text { profesního účetního }\end{array}$ & Pearson Chi-Square & $1,013^{\mathrm{a}}$ & 2 & $\mathbf{0 , 6 0 3}$ \\
\hline $\begin{array}{l}\text { Vliv kvalifikace účetní profese na } \\
\text { platové ohodnocení }\end{array}$ & Pearson Chi-Square & $13,615^{\mathrm{a}}$ & 2 & $\mathbf{0 , 0 0 1}$ \\
\hline $\begin{array}{l}\text { Vliv ekonomického poklesu na zvýšení } \\
\text { důležitosti účetní profese }\end{array}$ & Pearson Chi-Square & $19,349^{\mathrm{a}}$ & 2 & $\mathbf{6 , 2 8 5 E - 0 5}$ \\
\hline N of Valid Cases & 709 & & \\
\hline
\end{tabular}

Zdroj: vlastní zpracování v programu SPSS

Pouze v př́ípadě vnímání podnikatelského rizika při výběru profesního účetního je hodnota signifikance větší než 0,05 a tudíž nelze nulovou hypotézu zamítnou (tab. 1). Naproti tomu další dvě hladiny statistické významnosti jsou již menší než 0,05 , a proto zamítáme nulové hypotézy. Na základě těchto výsledků lze tedy konstatovat, že na formě vysokoškolského studia nezávisí vnímání podnikatelského rizika spojeného s výběrem profesního účetního, ale forma VŠ studia ovlivňuje vnímání, zda se úroveň kvalifikace profesních účetních projevuje na jejich platovém ohodnocení a zda vlivem ekonomického poklesu uplynulých let došlo ke zvýšení důležitosti profesních účetních pro podnikatele. Abychom zjistili intenzitu závislosti mezi nominálními proměnnými, byly pomocí programu SPSS spočítány koeficienty kontingence, které zobrazuje 
následující tabulka 2. Vzhledem k tomu, že se hodnoty obou koeficientů blíží 0 , nelze usuzovat na těsnou závislost.

Tabulka 2: Intenzita závislosti vnímání účetní profese podle formy studia

\begin{tabular}{|l|l|c|c|}
\hline \multicolumn{2}{|c|}{ Symmetric Measures } & Value & Appr. Sig. \\
\hline $\begin{array}{l}\text { Vliv kvalifikace účetní profese na } \\
\text { platové ohodnocení }\end{array}$ & Contingency Coefficient & $\mathbf{0 , 1 3 7}$ & 0,001 \\
\hline $\begin{array}{l}\text { Vliv ekonomického poklesu na zvýšení } \\
\text { dủležitosti účetní profese }\end{array}$ & Contingency Coefficient & $\mathbf{0 , 1 6 3}$ & $6,285 \mathrm{E}-05$ \\
\hline N of Valid Cases & & 709 & \\
\hline
\end{tabular}

Zdroj: vlastní zpracování v programu SPSS

Pro analýzu závislosti vnímání účetní profese na stupni vysokoškolského studia byly stanoveny další tři hypotézy:

- vnímání podnikatelského rizika spojeného s výběrem profesního účetního nezávisí na stupni vysokoškolského studia,

- vnímání, zda se úroveň kvalifikace profesních účetních projevuje na jejich platovém ohodnocení, nezávisí na stupni vysokoškolského studia,

- vnímání, zda vlivem ekonomického poklesu uplynulých let došlo ke zvýšení důležitosti profesních účetních pro podnikatele, nezávisí na stupni vysokoškolského studia.

Jak je patrno z tabulky 3 , všechny hodnoty signifikance jsou větší než 0,05 , a proto nelze nulové hypotézy zamítnout. Je tedy možné konstatovat, že s 95\% pravděpodobností vnímání účetní profese v ČR není závislé na stupni vysokoškolského studia.

Tabulka 3: Vnímání účetní profese podle stupně studia

\begin{tabular}{|l|c|c|c|c|}
\hline \multicolumn{2}{|c|}{ Chi-Square Tests } & Value & df & Asymp. Sig. \\
\hline $\begin{array}{l}\text { Podnikatelské riziko a výběr } \\
\text { profesního účetního }\end{array}$ & Pearson Chi-Square & $2,018^{\mathrm{a}}$ & 2 & $\mathbf{0 , 3 6 5}$ \\
\hline $\begin{array}{l}\text { Vliv kvalifikace účetní profese na } \\
\text { platové ohodnocení }\end{array}$ & Pearson Chi-Square & $5,477^{\mathrm{a}}$ & 2 & $\mathbf{0 , 0 6 5}$ \\
\hline $\begin{array}{l}\text { Vliv ekonomického poklesu na zvýšení } \\
\text { dủležitosti účetní profese }\end{array}$ & Pearson Chi-Square & $0,140^{\mathrm{a}}$ & 2 & $\mathbf{0 , 9 3 2}$ \\
\hline N of Valid Cases & 709 & & \\
\hline
\end{tabular}

Zdroj: vlastní zpracování v programu SPSS

V neposlední řadě byla také zkoumána závislost vnímání účetní profese na oboru vysokoškolského studia. Pro testování byly stanoveny tyto hypotézy:

- vnímání podnikatelského rizika spojeného s výběrem profesního účetního nezávisí na oboru studia,

- vnímání, zda se úroveň kvalifikace profesních účetních projevuje na jejich platovém ohodnocení, nezávisí na oboru studia,

- vnímání, zda vlivem ekonomického poklesu uplynulých let došlo ke zvýšení důležitosti profesních účetních pro podnikatele, nezávisí na oboru studia.

Následující tabulka 4 zobrazuje hladiny statistické významnosti, ze kterých je patrno, že ve dvou př́ípadech nelze nulovou hypotézu zamítnout, nebot' hodnoty signifikance jsou větší než 0,05. Z těchto výsledků tedy vyplývá, že vnímání podnikatelského rizika spojeného s výběrem profesního účetního a vnímání vlivu ekonomického poklesu uplynulých let na zvýšení důležitosti profesních účetních pro podnikatele není závislé na oboru studia. 
Tabulka 4: Vnímání účetní profese podle oboru studia

\begin{tabular}{|l|c|c|c|c|}
\hline \multicolumn{2}{|c|}{ Chi-Square Tests } & Value & df & Asymp. Sig. \\
\hline $\begin{array}{l}\text { Podnikatelské riziko a výběr } \\
\text { profesního účetního }\end{array}$ & Pearson Chi-Square & $4,755^{\text {a }}$ & 2 & $\mathbf{0 , 0 9 3}$ \\
\hline $\begin{array}{l}\text { Vliv kvalifikace účetní profese na } \\
\text { platové ohodnocení }\end{array}$ & Pearson Chi-Square & $12,451^{\text {a }}$ & 2 & $\mathbf{0 , 0 0 2}$ \\
\hline $\begin{array}{l}\text { Vliv ekonomického poklesu na zvýšení } \\
\text { dủležitosti účetní profese }\end{array}$ & Pearson Chi-Square & $4,242^{\text {a }}$ & 2 & $\mathbf{0 , 1 2 0}$ \\
\hline N of Valid Cases & 709 & & \\
\hline
\end{tabular}

Zdroj: vlastní zpracování v programu SPSS

Zamítáme pouze hypotézu, že vnímání, zda se úroveň kvalifikace profesních účetních projevuje na jejich platovém ohodnocení, nezávisí na oboru studia. Také v tomto prípadě byl spočítán koeficient kontingence pro zjištění intenzity závislosti a vzhledem k tomu, že se jeho hodnota blíží 0 , nelze usuzovat na těsnou závislost (tab. 5).

Tabulka 5: Intenzita závislosti vnímání účetní profese podle oboru studia

\begin{tabular}{|l|l|c|c|}
\hline \multicolumn{2}{|c|}{ Symmetric Measures } & Value & Appr. Sig. \\
\hline $\begin{array}{l}\text { Vliv kvalifikace účetní profese na } \\
\text { platové ohodnocení }\end{array}$ & Contingency Coefficient & $\mathbf{0 , 1 3 1}$ & 0,002 \\
\hline N of Valid Cases & 709 & \\
\hline
\end{tabular}

Zdroj: vlastní zpracování v programu SPSS

\subsection{Závislost vnímání účetní profese na zaměstnání}

Prověření závislosti vnímání účetní profese na zaměstnání bylo uskutečněno pomocí testování následujících hypotéz:

- vnímání podnikatelského rizika spojeného s výběrem profesního účetního nezávisí na zaměstnání,

- vnímání, zda se úroveň kvalifikace profesních účetních projevuje na jejich platovém ohodnocení, nezávisí na zaměstnání,

- vnímání, zda vlivem ekonomického poklesu uplynulých let došlo ke zvýšení důležitosti profesních účetních pro podnikatele, nezávisí na zaměstnání.

Tabulka 6: Vnímání účetní profese podle zaměstnání

\begin{tabular}{|l|c|c|c|c|}
\hline \multicolumn{2}{|c|}{ Chi-Square Tests } & Value & df & Asymp. Sig. \\
\hline $\begin{array}{l}\text { Podnikatelské riziko a výběr } \\
\text { profesního účetního }\end{array}$ & Pearson Chi-Square & $10,920^{\mathrm{a}}$ & 4 & $\mathbf{0 , 0 2 7}$ \\
\hline $\begin{array}{l}\text { Vliv kvalifikace účetní profese na } \\
\text { platové ohodnocení }\end{array}$ & Pearson Chi-Square & $23,608^{\mathrm{a}}$ & 4 & $\mathbf{9 , 5 7 2 E - 0 5}$ \\
\hline $\begin{array}{l}\text { Vliv ekonomického poklesu na zvýšení } \\
\text { důležitosti účetní profese }\end{array}$ & Pearson Chi-Square & $13,010^{\mathrm{a}}$ & 4 & $\mathbf{0 , 0 1 1}$ \\
\hline N of Valid Cases & 709 & & \\
\hline
\end{tabular}

Zdroj: vlastní zpracování v programu SPSS

$\mathrm{Na}$ základě zjištěných hladin statistické významnosti z tabulky 6 , kde všechny hodnoty signifikance jsou menší než 0.05 , lze nulové hypotézy zamítnout. S 95\% pravděpodobností můžeme konstatovat, že vnímání účetní profese v České republice je závislé na zaměstnání.

Pomocí programu SPSS byly dále spočítány koeficienty kontingence pro zjištění intenzity závislosti mezi nominálními proměnnými. Jak vyplývá z následující tabulky 7 , hodnoty všech koeficientů se blíží 0 , tudíž ani v jednom př́padě nelze usuzovat na těsnou závislost. 
Tabulka 7: Intenzita závislosti vnímání účetní profese podle zaměstnání

\begin{tabular}{|l|l|c|c|}
\hline \multicolumn{2}{|c|}{ Symmetric Measures } & Value & Appr. Sig. \\
\hline $\begin{array}{l}\text { Podnikatelské riziko a výběr } \\
\text { profesního účetního }\end{array}$ & Contingency Coefficient & $\mathbf{0 , 1 2 4}$ & 0,027 \\
\hline $\begin{array}{l}\text { Vliv kvalifikace účetní profese na } \\
\text { platové ohodnocení }\end{array}$ & Contingency Coefficient & $\mathbf{0 , 1 8 0}$ & $9,572 \mathrm{E}-05$ \\
\hline $\begin{array}{l}\text { Vliv ekonomického poklesu na zvýšení } \\
\text { důležitosti účetní profese }\end{array}$ & Contingency Coefficient & $\mathbf{0 , 1 3 5}$ & 0,011 \\
\hline N of Valid Cases & 709 & \\
\hline
\end{tabular}

Zdroj: vlastní zpracování v programu SPSS

\section{Závěr}

Cílem článku bylo zhodnotit vnímání účetní profese v České republice studenty prezenční a kombinované formy studia na Obchodně podnikatelské fakultě v Karviné. Pro určení závislosti vnímání účetní profese na formě vysokoškolského studia, stupni vysokoškolského studia, oboru vysokoškolského studia a zaměstnání byly stanoveny následující hypotézy, jež byly rozděleny do 4 skupin (dle formy vysokoškolského studia, stupně vysokoškolského studia, oboru vysokoškolského studia a zaměstnání).

Pomocí Pearsonova chí-kvadrát testu a Pearsnova koeficientu kontingence bylo zjištěno, že vnímání podnikatelského rizika spojeného s výběrem profesního účetního nezávisí na formě vysokoškolského studia. Na druhou stranu bylo prokázáno, že forma vysokoškolského studia ovlivňuje vnímání, zda se úroveň kvalifikace profesních účetních projevuje na jejich platovém ohodnocení a zda vlivem ekonomického poklesu uplynulých let došlo ke zvýšení důležitosti profesních účetních pro podnikatele.

Výsledky také prokázaly, že vnímání účetní profese v České republice není závisle na stupni vysokoškolského studia. Z výsledků také vyplývá, že vnímání podnikatelského rizika spojeného s výběrem profesního účetního a vnímání vlivu ekonomického poklesu uplynulých let na zvýšení důležitosti profesních účetních pro podnikatele není závislé na oboru studia. Dále bylo prokázáno, že vnímání účetní profese v České republice je závislé na zaměstnání.

Současně je nutno mít na zřeteli, že výsledky a závěry dotazníkového šetření mohou být ovlivněny zjednodušeným vnímáním účetní profese respondenty, kteří se mnohem častěji setkali s účetní profesí, kdy účetní zajištuje ucelené části účetního systému firmy a provádí účetní operace na jednotlivých účtech nebo skupinách účtů, než s účetními experty zabývajícími se fưzemi, konsolidacemi, př́ípadně auditem.

\section{Poděkování}

„Tento článek vznikl za podpory Ministerstva školství, mládeže a tělovýchovy ČR v rámci Institucionální podpory na dlouhodobý koncepční rozvoj výzkumné organizace v roce 2018 “

\section{Literatura}

[1] ACCA, 2012. 100 drivers of change for the global accountancy profession. The Association of Chartered Certified Accountants, September. [online]. London: ACCA [vid. 24. ř́ijna 2018]. Dostupné $\mathrm{z}$ : www.accaglobal.com/content/dam/acca/global/PDFtechnical/ futures/pol-af-doc.pdf (10.03.2016).

[2] GIBASSIER, D., M. RODRIGUE and D. L. ARIALIÈS, 2015. From Share Value to Shared Value: Exploring the Role of Accountants in Developing Integrated Reporting in Practice [online]. IMA-ACCA. [vid. 24. ř́́jna 2018]. Dostupné z: 
www.imanet.org/docs/default-source/thought_leadership/from-share-value-to-sharedvalue_02-01-16-final. pdf?sfvrsn=2 (10.03.2016).

[3] IFAC, 2011. Sustainability framework 2.0. Professional accountants as integrators. [online]. Laxemburg: IFAC [vid. 24. října 2018]. Dostupné z: www.accountability.org/images/content/4/3/435.pdf (10.03.2016)

[4] JAWORSKA, E., 2016. Rachunkowość w zarządzaniu jednostkami gospodarczymi. Finanse, Rynki Finansowe, Ubezpieczenia. 3(81). 123-131.

[5] OTRUSINOVÁ, M. and K. ŠTEKER, 2013. An Analysis of Using Accounting Information for Financial Management in Czech Companies. International Journal of Mathematical Models and Methods in Applied Sciences, 7(4), 436-443.

[6] PASEKOVÁ, M., B. SVITÁKOVÁ, E. KRAMNÁ, M. OTRUSINOVÁ, E. KOLÁŘOVÁ and Z. CRHOVÁ, 2018. Problematic areas of accounting: some evidence from the Czech Republic. Journal of Competitiveness 10 (1), 89-105.

[7] PUICAN, L., M. AVRAM and M. DUTESCU. 2011. The Importance of Accounting Information Quality in the Performance of Statutory Audit. Annals of University of Craiova - Economic Sciences, 3 (39), 50-55.

[8] SUDDABY, R., Y. GENDRON and H. LAM. 2009. The organizational context of professionalism in ing. Accounting, Organizations and Society, 34 (3-4), 409-427.

[9] WORLD IDG CZECH REPUBLIC, a. s., 2013. [online]. Boston: World IDG [vid. 24. ř́ijna 2018]. Dostupné $\mathrm{z}$ : https://cfoworld.cz/financni-sluzby/katerina-sipkova-accaucetni-mohou-ucinne-stabilizovat-byznys-2620CFO. 